\section{Synthesis and characterization of novel acrylamide-based ternary polyampholyte as tracer} agent

I. Gussenov ${ }^{1 *}$, N. Mukhametgazy ${ }^{1,2}$ A.V. Shakhvorostov ${ }^{1}$, S.E. Kudaibergenov

${ }^{1}$ Institute of Polymer Materials and Technology, Almaty, Kazakhstan ${ }^{2}$ Satbayev University, Almaty, Kazakhstan *E-mail: iskander.gussenov@gmail.com
A novel ternary polyampholyte composed of fully charged anionic monomer-2-acrylamido2-methyl-1-propanesulfonic acid sodium salt (AMPS), cationic monomer - (3-acrylamidopropyl) trimethylammonium chloride (APTAC) and the positively charged fluorescent dye - acrylamide Nile Blue (ANB) was synthesized by conventional free radical copolymerization and characterized by FTIR, UV-Vis, fluorescence spectroscopy, dynamic light scattering and zeta-potential. FTIR spectrum of AMPS-APTAC-ANB shows that introduction of $1 \mathrm{~mol} \%$ ANB into copolymer composition does not influence the basic characteristic bands of polyampholyte. The adsorption and emission peaks of AMPS-APTAC-ANB found at $\lambda_{\text {max }}=586 \mathrm{~nm}$ and $\lambda_{\max }=660-680 \mathrm{~nm}$ are attributed to ANB groups of terpolymer. The average hydrodynamic size and zeta potential of AMPS-APTAC-ANB in aqueous solution that are equal to $4.3 \mathrm{~nm}$ and $\xi=-1.6 \mathrm{mV}$ indicating the globular conformation of amphoteric macromolecules with a slightly negative charge. Injection of 0.1 wt.\% (or $1.3 \cdot 10^{-3} \mathrm{~mol} \cdot \mathrm{L}^{-1}$ ) AMPS-APTAC-ANB into the core sample derived from the "Vostochnyi Moldabek" oilfield demonstrated the passing of fluorescently-labeled terpolymer through the core. The ternary polyampholyte containing the fluorescent marker can serve as oilfield tracer for monitoring well-to-well connections (or interwell tracer test). tracer.

Keywords: ternary polyampholyte; synthesis; characterization; core flooding; filtration;

\section{Жаңа акриламид негізіндегі үштік полиамфолиттің іздеуші агент ретіндегі синтезі жіне сипаттамасы}

И. Гусенов ${ }^{1 *}$, Н. Мұхаметғазы ${ }^{1,2}$ А.В. Шахворостов ${ }^{1}$, С.Е. Құдайбергенов

${ }^{1}$ Полимерлік материалдар және технологиялар институть, Алматы, Қазақстан

${ }^{2}$ Сәтбаев Университеті, Алматы, Қазақстан

*E-mail: iskander.gussenov@gmail.com

Толық зарядталған жаңа үштік құрлымды полиамфолит, аниондық мономер 2-акриламидо-2-метил-1-пропансульфон қышқылды натрий тұзы (АМПСҚ), катионды мономер - (3-акриламидопропил) триметиламмоний хлориді (АПТМАХ) және оң зарядталған флуоресцентті бояу - акриламид нил көк (АНК) бос радикалды сополимерлену әдісімен синтезделді және ол Иқ-Фурье спектроскопия, ультракүлгін-көрініс және флуоресценттік спектроскопиямен, жарықтың динамикалық шашырауы және дзета потенциалы арқылы сипатталады. АМПСҚ-АПТМАХ-АНК спектрі 1 моль.\% АНК енгізілгенін көрсетеді, ол сополимердегі полиамфолиттің негізгі сипаттамалық жолақтарына әсер етпейді. Максималды $\lambda_{\text {мах }}=586$ нм және $\lambda_{\text {max }}=660-680$ нм болатын АМПСҚ-АПТМАХ-АНК жұтылу мен сәулелену шыңдары, терполимердің АНК топтарына жатады. АМПСҚ-АПТМАХАНК-ның су ертіндісіндегі орташа гидродинамикалық мөлшері мен дзета потенциалы, сәйкесінше 4,3 нм және $\xi=-1,6$ мВ болатын амфотерлі макромолекулалардың глобулалық конформациясымен бірге әлсіз заряды бар екенін көрсетті. Шығыс Молдабек кен орнынан

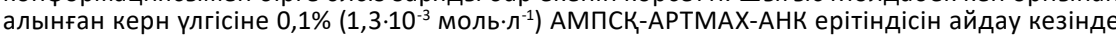
флуоресцентті белгіленген терполимердің керн арқылы тау жынысына адсорбциясыз өткендігін көрсетті. Флуоресцентті белгісі бар үштік полиамфолит ұңғымалар арасындағы байланыстарды бақылауға арналған мұнай кен орындарын іздестіру қызметін атқара алады немесе ұңғыма ішіндегі іздеу сынағы ретінде қолданыс табады. трасcер.

Түйін сөздер: үштік полиамфолит; синтез; сипаттама; керн арқылы айдау; сүзу

\section{Синтез и исследование нового тройного полиамфолита на основе акриламида в качестве трассерного агента}

И. Гусенов ${ }^{1 *}$, Н. Мухаметгазы $\mathbf{1}^{1,2}$ А.В. Шахворостов ${ }^{1}$, С.Е. Кудайбергенов

${ }^{1}$ Институт полимерных материалов и технологий, Алматы, Казахстан ${ }^{2}$ Satbayev University, Алматы, Казахстан *E-mail: iskander.gussenov@gmail.com
Новый тройной полиамфолит, состоящий из сильнозаряженного анионного мономера - натриевой соли 2-акриламидо-2-метил-1-пропансульфоновой кислоты (АМПС), катионного мономера - (3-акриламидопропил) триметиламмоний хлорида (АПТАХ) и положительно заряженного флуоресцентного красителя - акриламид Нил голубого (АНГ) синтезирован методом свободнорадикальной сополимеризации и он охарактеризован методами ИК-Фурье, УФ видимой и флуоресцентной спектроскопии, динамического светорассеяния и дзета-потенциала. ИК-Фурье спектр АМПС-АПТАХ-АНГ показывает, что введение 1 мол. \% АНГ в состав сополимера не влияет на основные характеристичные полосы полиамфолита. Адсорбционный и эмиссионный пики АМПС-АПТАХ-АНГ максимумами при $\lambda_{\text {max }}=586 \mathrm{HM}$ и $\lambda_{\text {max }}=660-680 \mathrm{HM}$ приписываются АНГ группам терполимера. Среднегидродинамический размер и дзета-потенциал АМПС-АРТАХ-АНГ в водном растворе, равные 4,3 нм и $\xi=-1,6$ мВ указывают на глобулярную конформацию амфотерных макромолекул со слабовыраженным отрицательным зарядом. Закачка

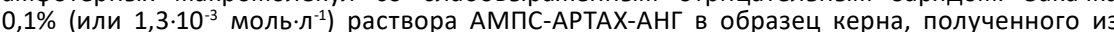
месторождения «Восточный Молдабек» показала прохождение флуоресцентно-меченого терполимера через керн. Тройной полиамфолит, содержащий флуоресцентный маркер может служить в качестве трассера при мониторинге межскважинного пространства нефтяных скважин.

Ключевые слова: полиамфолитный тройной сополимер; синтез; характеристики; заводнение керна; фильтрация; трассер. 


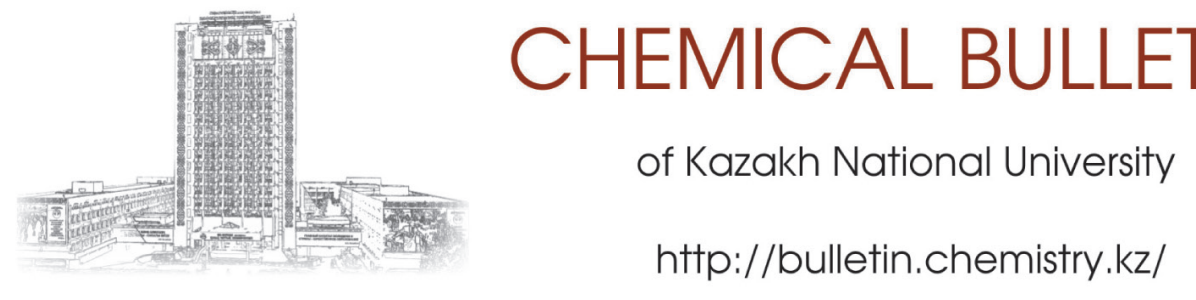

\title{
Synthesis and characterization of novel acrylamide-based ternary polyampholyte as tracer agent
}

\author{
I. Gussenov ${ }^{1 *}$, N. Mukhametgazy ${ }^{1,2}$, A.V. Shakhvorostov ${ }^{1}$ (D) , S.E. Kudaibergenov ${ }^{1}$ \\ ${ }^{1}$ Institute of Polymer Materials and Technologies, 1/3 microdistrict "Atyrau 1", Almaty 050019, Kazakhstan \\ ${ }^{2}$ Satbayev University, 22a Satpaev str., Almaty 050013, Kazakhstan \\ *E-mail: iskander.gussenov@gmail.com
}

(This paper is dedicated to $70^{\text {th }}$ anniversary of Professor Sarkyt E. Kudaibergenov)

\section{Introduction}

The strongly charged or "quenched" polyampholyte (QPA) represents a macromolecule consisting of static positive and negative charges independently on $\mathrm{pH}$ [1-3]. Earlier [4-7] we have considered the behavior of linear and crosslinked QPA based on fully charged anionic monomer - 2-acrylamido-2methyl-1-propanesulfonic acid sodium salt (AMPS) and cationic monomer - (3-acrylamidopropyl) trimethylammonium chloride (APTAC) in aqueous-salt solutions, complexation ability with respect to ionic dyes, surfactants, swelling and mechanical properties. Later on $[8,9]$ we have reported the applicability of amphoteric terpolymers composed of AMPS, APTAC and acrylamide (AAm) as viscosifying agent in enhanced oil recovery (EOR). Equimolar QPA based on AMPS-APTAC dissolved in saline water with mineralization more than $200 \mathrm{~g} \cdot \mathrm{L}^{-1}$ was also tested to evaluate the flow behavior through porous media [10]. It was found that AMPS-APTAC solution is able to pass through the porous media model. This invoked us to synthesize equimolar QPA composed of equal numbers of anionic and cationic monomers containing also a small amount of fluorescent monomer - acrylamide Nile Blue for application as an interwell tracer agent. The main reason of selection of ternary copolymer AMPS-APTAC-ANB as polymeric tracer is that it is water-soluble, highly stable thermally, chemically, physically, and biologically in oil reservoir conditions, salt tolerant in oilfield water, detectable in very low concentrations, low toxic, and has minimal adsorption to the rock [11]. In the present communication we demonstrate that the transport behavior of ternary copolymer AMPS-APTACANB through the core can open new smart tracing possibilities for monitoring well-to-well connections.

\section{Experiment}

2.1. Materials

2-acrylamido-2-methylpropanesulfonic acid sodium salt (AMPS, $98 \mathrm{wt} . \%$ in water) and (3-acrylamidopropyl) trimethylammonium chloride (APTAC, $75 \mathrm{wt} . \%$ in water), acrylamide Nile Blue (ANB, dark blue crystals, purity 99\%) and ammonium persulfate (APS, purity 99\%) were purchased from Sigma-Aldrich Chemical Co. and used without further purification. The core sample of $3.9 \mathrm{~cm}$ length and $2.95 \mathrm{~cm}$ diameter purchased from "Vostochnyi Moldabek" oilfield $\# 2524$ from the depth of $\approx 500 \mathrm{~m}$ has the porosity of $0.094 \%$ and permeability of $1 \mathrm{mD}$. According to elemental analysis the core sample mostly consists of aluminosilicates of calcium, iron and potassium. Brine solution from "Vostochnyi Moldabek" oilfield \#2524 with mineralization $100 \mathrm{~g} \cdot \mathrm{L}^{-1}$ was used for core flooding test.

\subsection{Methods}

Absorption, fluorescence and FT-IR spectra of AMPSAPTAC-ANB were registered on UV-Vis spectrophotometer (Specord 210 plus BU, Germany), F97 Pro fluorescence spectrophotometer (China) and Carry 660 (Agilent, USA), respectively. The fluorescence spectrum of AMPS-APTAC-ANB was recorded at emission wavelength $\lambda_{\max }=660-680 \mathrm{~nm}$ that is very close to emission spectrum of monomeric ANB in water $\left(\lambda_{\max }=674 \mathrm{~nm}\right)$. The average hydrodynamic size and $\zeta$-potential of AMPS-APTAC-ANB were determined with the help of a dynamic light scattering (DLS) device (Malvern Zetasizer Nano ZS90, UK). The core flooding experiments were conducted with the help of special core flooding set up "УИК-С(2)" (Russia). 


\section{Results and Discussion}

3.1. Synthesis and characterization of AMPS-APTAC-ANB terpolymer

Acrylamide-based ternary polyampholyte AMPS-APTACANB was synthesized via conventional free radical (co) polymerization at the molar ratio of initial monomers [AMPS]:[APTAC]:[ANB] $=50: 49: 1$ in the presence of APS at $60^{\circ} \mathrm{C}$ during $4 \mathrm{~h}$ (Figure 1).

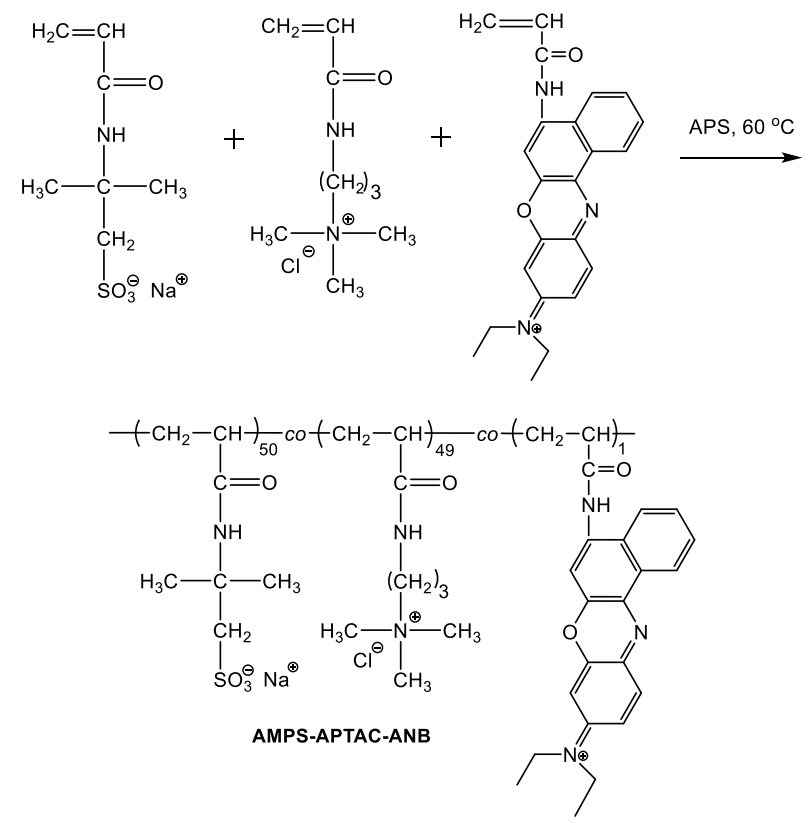

Figure 1 - Synthetic protocol of AMPS-APTAC-ANB terpolymer
Figure 2 and Table 1 show the FTIR spectrum and characteristic bands of functional groups of AMPS-APTAC-ANB.

FTIR spectra of AMPS-APTAC (50:50 mol.\%) and AMPSAPTAC-ANB (50:49:1 mol.\%) are identical, meaning that $1 \mathrm{~mol} . \%$ of ANB in terpolymer composition does not influence the characteristic bands of polyampholytes [4]. UV-Vis spectra of AMPS-APTAC-ANB in aqueous solution exhibit well defined absorption maximum at $\lambda_{\text {max }}=586 \mathrm{~nm}$ that is attributed to ANB group of terpolymer (Figure 3 ).

The average hydrodynamic size and zeta potential of AMPS-APTAC-ANB in aqueous solution are equal to $4.3 \mathrm{~nm}$ and $\xi=-1.6 \mathrm{mV}$, respectively, that indicate on globular conformation of amphoteric macromolecules with slightly negative surface charge (Figure 4).

In pure water the AMPS-APTAC-ANB macromolecules are in globular state due to electrostatic attraction between oppositely charged monomer units. It is likely that the ANB molecules due to more hydrophobic character are replaced inside of globules as shown in Figure 5. It is expected that due to slightly negative surface charge of the AMPS-APTAC-ANB $(\xi=$ $-1.6 \mathrm{mV}$ ) its adsorption to negatively charged surface of core materials is minimal or even excluded.

3.2. Core flooding experiments with AMPS-APTAC-ANB solution

The fluorescence-detection technology attracts considerable interest in oilfield operations [11] due to many advantages over radioactive isotopes, ionic and organic tracers [12]. For evaluation of interwell permeability and porosity the authors [13] used fluorescent polyacrylamide microspheres, which fluoresce under ultraviolet irradiation. A water-soluble

Table 1 - Identification of FTIR spectrum of AMPS-APTAC-ANB

\begin{tabular}{lllllll}
\hline Functional groups & $v(\mathrm{NH})$ & $v(\mathrm{CH})$ & $\begin{array}{l}v(\mathrm{CONH}) \\
\text { Amide I }\end{array}$ & $\begin{array}{l}v(\mathrm{CONH}) \\
\text { Amide II }\end{array}$ & $\delta(\mathrm{CH})$ \\
\hline Band assignments, $\mathrm{cm}^{-1}$ & 3427 & 2938 & 1649 & 1550 & 1185 \\
\hline
\end{tabular}

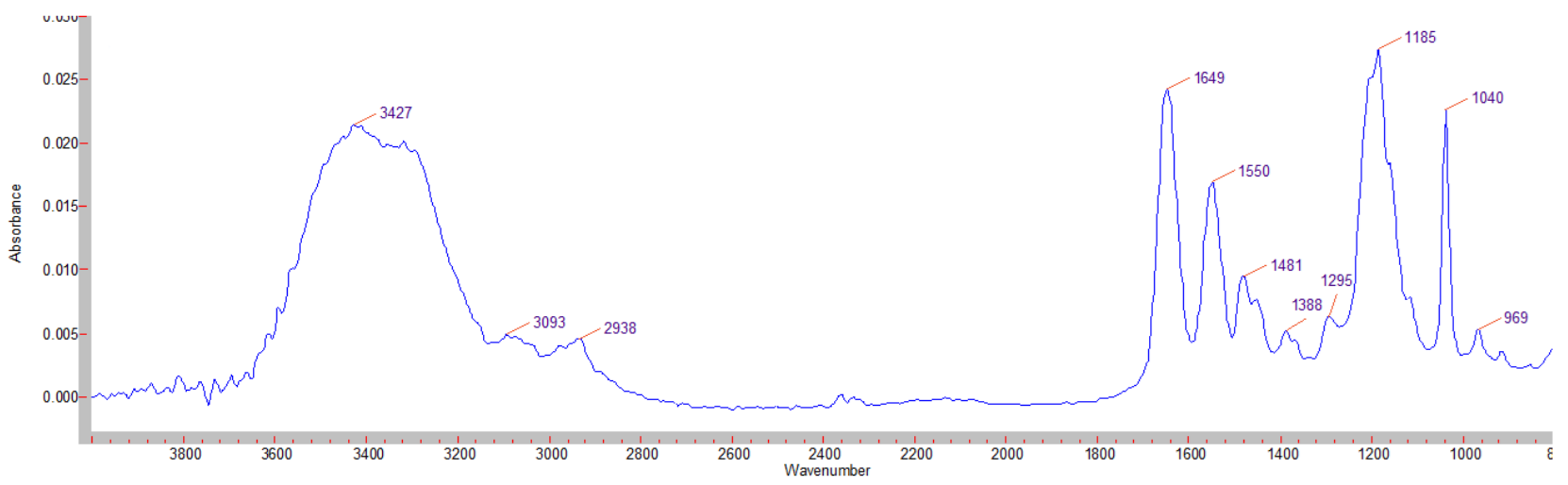

Figure 2 - FTIR spectrum of AMPS-APTAC-ANB 

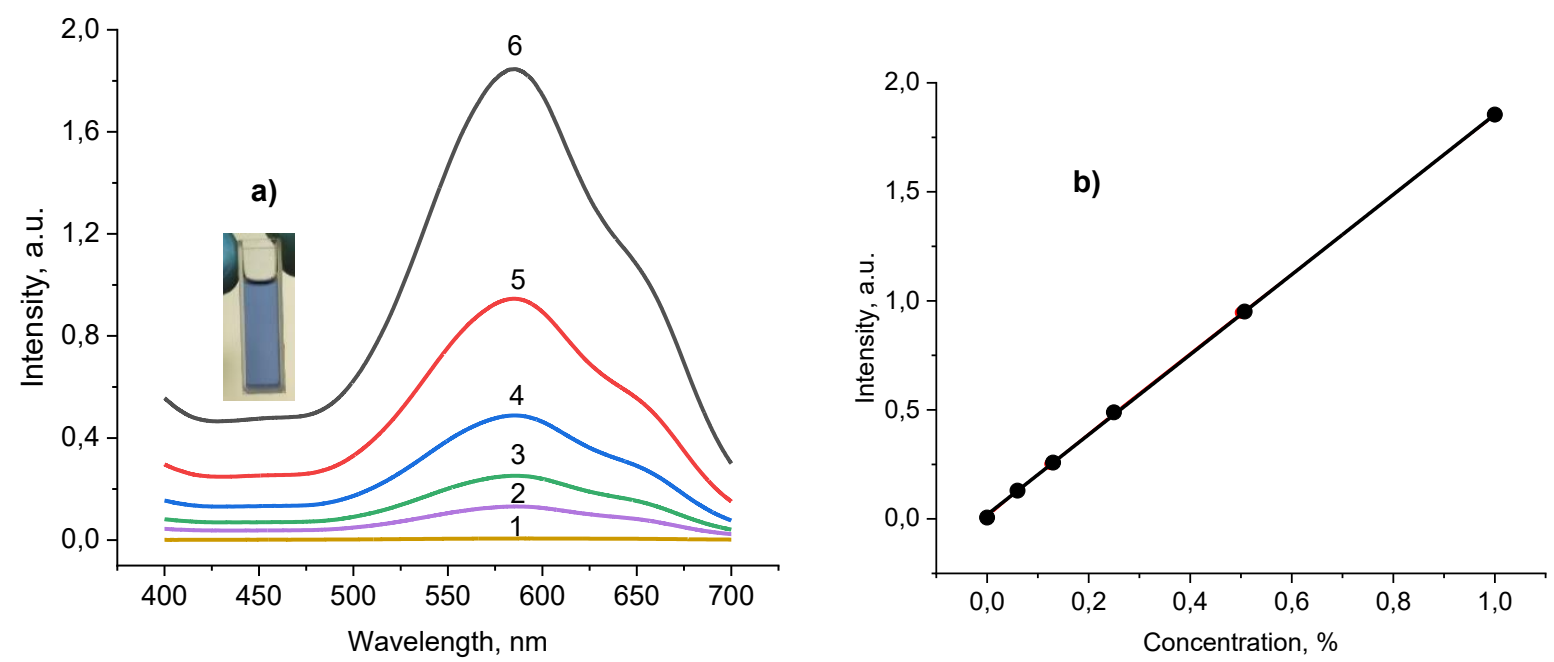

Figure 3 - Visible spectra of AMPS-APTAC-ANB in aqueous solution (a) and calibration graph (b) plotted in coordinates "intensityconcentration" at concentration of [AMPS-APTAC-ANB] = 0 (1), 0.0625 (2), 0.125 (3), 0.25 (4), 0.5 (5) and 1.0 wt.\% (6). Insert is a quartz cuvette containing aqueous solution of AMPS-APTAC-ANB.
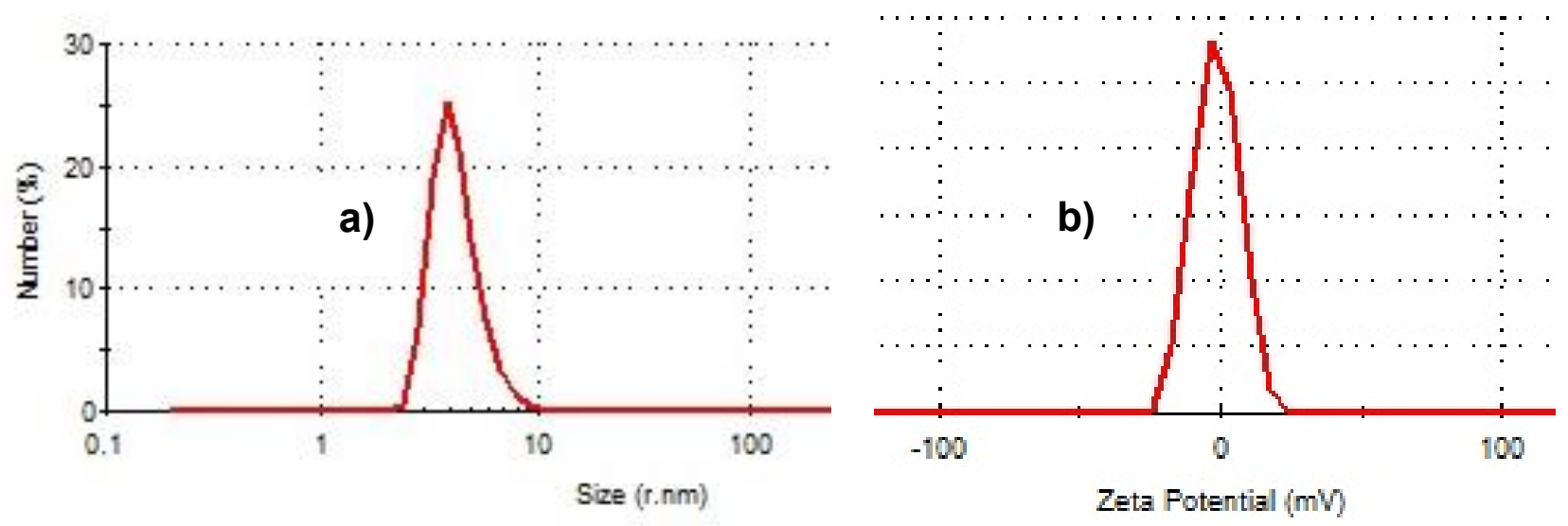

Figure 4 - The average hydrodynamic diameter (a) and the value of zeta-potential (b) of 0.15 wt.\% AMPS-APTAC-ANB in aqueous solution

a)

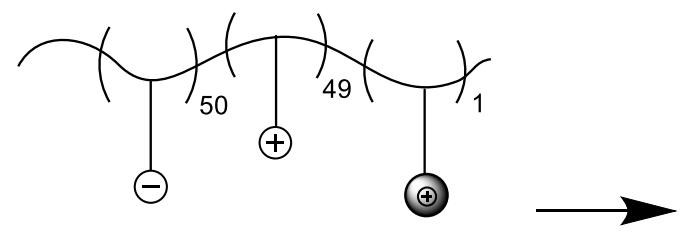

AMPS $_{50}-$ APTAC $_{49}-\mathrm{ANB}_{1}$

$\ominus$ AMPS

(†) APTAC

(†) ANB b)
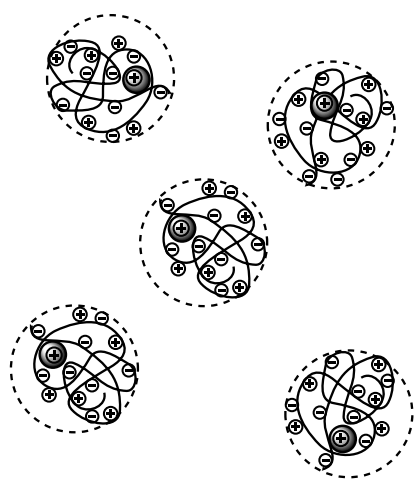

Figure 5 - Schematic representation of structural unit of amphoteric terpolymer AMPS-APTAC-ANB (a) and formation of globular structure (b) in dilute aqueous solution 
fluorescent polymer was prepared as a combination of a flooding agent and tracer by introducing a polymerizable rigid fluorescent coumarin monomer into polyacrylamide chains [14]. Fluorescent polymer microspheres were also obtained via the inverse suspension polymerization method with Rhodamine $B$ as a fluorescence functional monomer [15]. As distinct from the abovementioned studies, in our case we have introduced a trace amount of fluorescent monomer acrylamide Nile Blue (ANB) into the composition of AMPS-APTAC quenched polyampholyte to prepare globular and fully electroneutral macromolecular chains to minimize or exclude their adsorption to the rock. The advantages of our approach are that the QPA of equimolar composition is water-soluble, salt tolerant and adopts globular and quasi-electroneutral conformation in aqueous solution due to mutual compensation of positive and negative charges. The core flooding experiments were conducted in the following sequence. At first, $40 \mathrm{~mL}$ of distilled water was injected into the core sample at $1 \mathrm{~mL} \cdot \mathrm{min}^{-1}$. In the course of water injection, the pressure sharply increased during $5 \mathrm{~min}$ and leveled off at $\mathrm{P}=0.08-0.10 \mathrm{MPa}$ during 10-90 min. The effluents were slightly turbid due to washing out of fine dispersed microparticles present in the core sample. In the next stage $50 \mathrm{~mL}, 0.1 \mathrm{wt} \%$ (or $1.3 \cdot 10^{-3} \mathrm{~mol} \cdot \mathrm{L}^{-1}$ ) aqueous solution of AMPS-APTAC-ANB were injected into the core sample preliminary washed out by distilled water (Figure 6). The injection rate of AMPS-APTAC-ANB was equal to $0.1 \mathrm{~mL} \cdot \mathrm{min}^{-1}$. In the course of the test the injection pressure was increasing gradually and blue color appeared in the collected effluents.

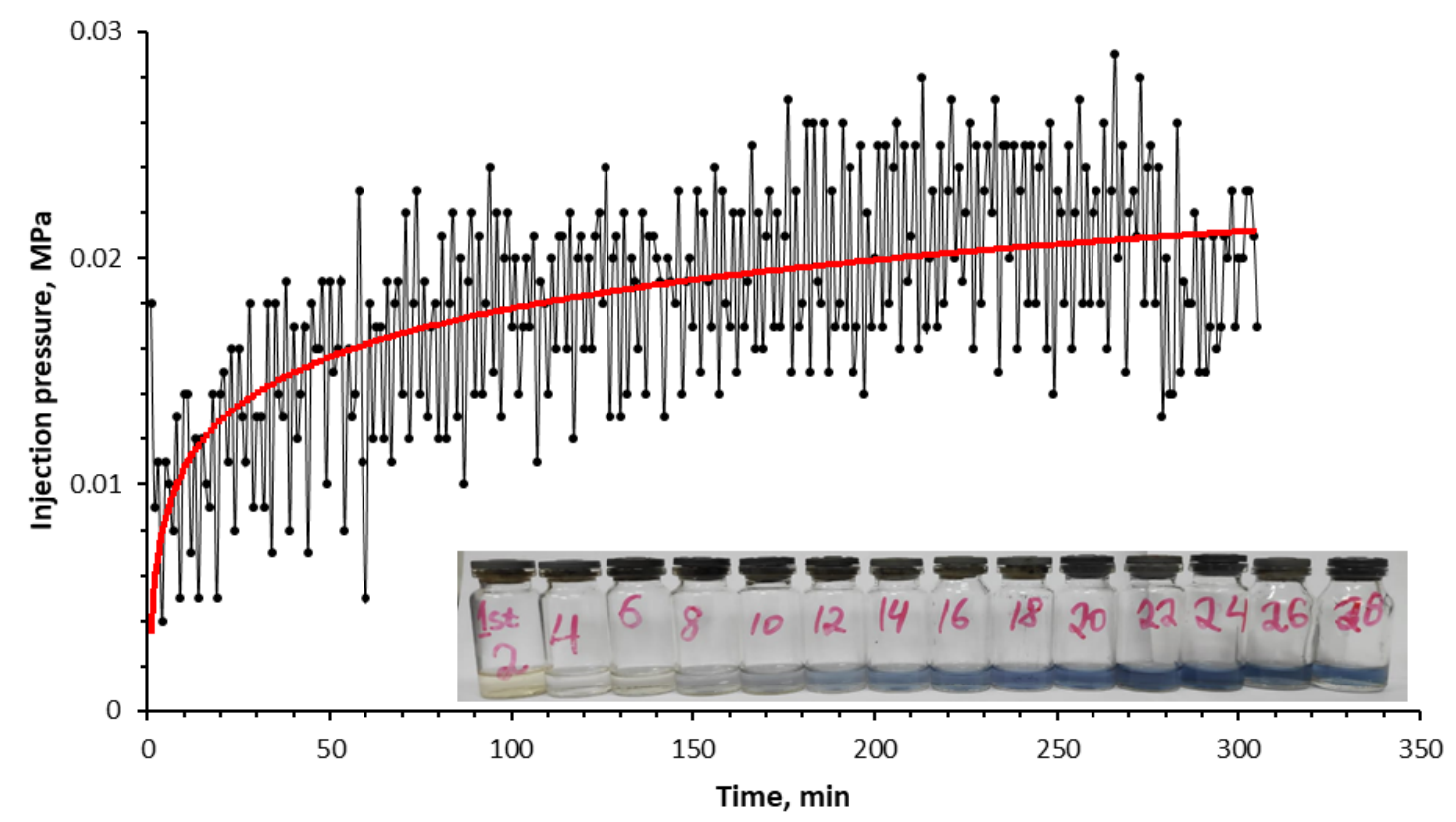

Figure 6 - Time-dependent change of pressure upon injection of AMPS-APTAC-ANB solution into the core sample and vials of collected effluents at $\mathrm{T}=25^{\circ} \mathrm{C}$

Chase saline water flooding with salinity $100 \mathrm{~g} \cdot \mathrm{L}^{-1}$ shows the linear increase in the pressure and replacement of residual amount of AMPS-APTAC-ANB entrapped within the core (Figure 7).

The presence of color initial 3 fractions of passed saline water confirm the replacement of AMPS-APTAC-ANB in core sample by saline water. The effluents were analyzed by UV-Vis at $\lambda_{\max }=586 \mathrm{~nm}$ and fluorescence spectrophotometer at emission wavelength $\lambda_{\max }=660-680 \mathrm{~nm}\left(\lambda_{\max }\right.$ of pure ANB in water is $674 \mathrm{~nm}$ ) to determine the concentration of AMPSAPTAC-ANB passed through the core and displaced by saline water (Figure 8).

The fluorescence intensity of AMPS-APTAC-ANB gradually increases after injection of the first $6 \mathrm{~mL}$ of polyampholyte solution (Region 1). This is probably due to the dilution of polyampholyte by residual distilled water left in the core sample. A sharp increase in the fluorescence intensity is observed after injection of $7 \mathrm{~mL}$ of polyampholyte solution through the core. It means that the main portion of AMPSAPTAC-ANB passes through the core in Region 2. The fluorescence intensity of AMPS-APTAC-ANB levels off in Region 3 after injection of $12-25 \mathrm{~mL}$ of polyampholyte solution meaning that the core sample is fully saturated by fluorescently-labeled polyampholyte. Pumping of $100 \mathrm{~g} \cdot \mathrm{L}^{-1}$ saline water into the core saturated by $0.1 \mathrm{wt} . \%$ AMPS-APTAC-ANB leads to the gradual decrease of the fluorescence intensity of polyampholyte solution. It is related to the replacement of AMPS-APTAC-ANB with saline water. After the injection of $28 \mathrm{~mL}$ saline water the fluorescence intensity of AMPS-APTAC-ANB decreases up to 38.5 a.u. It is 10 times lower than the initial concentration of 


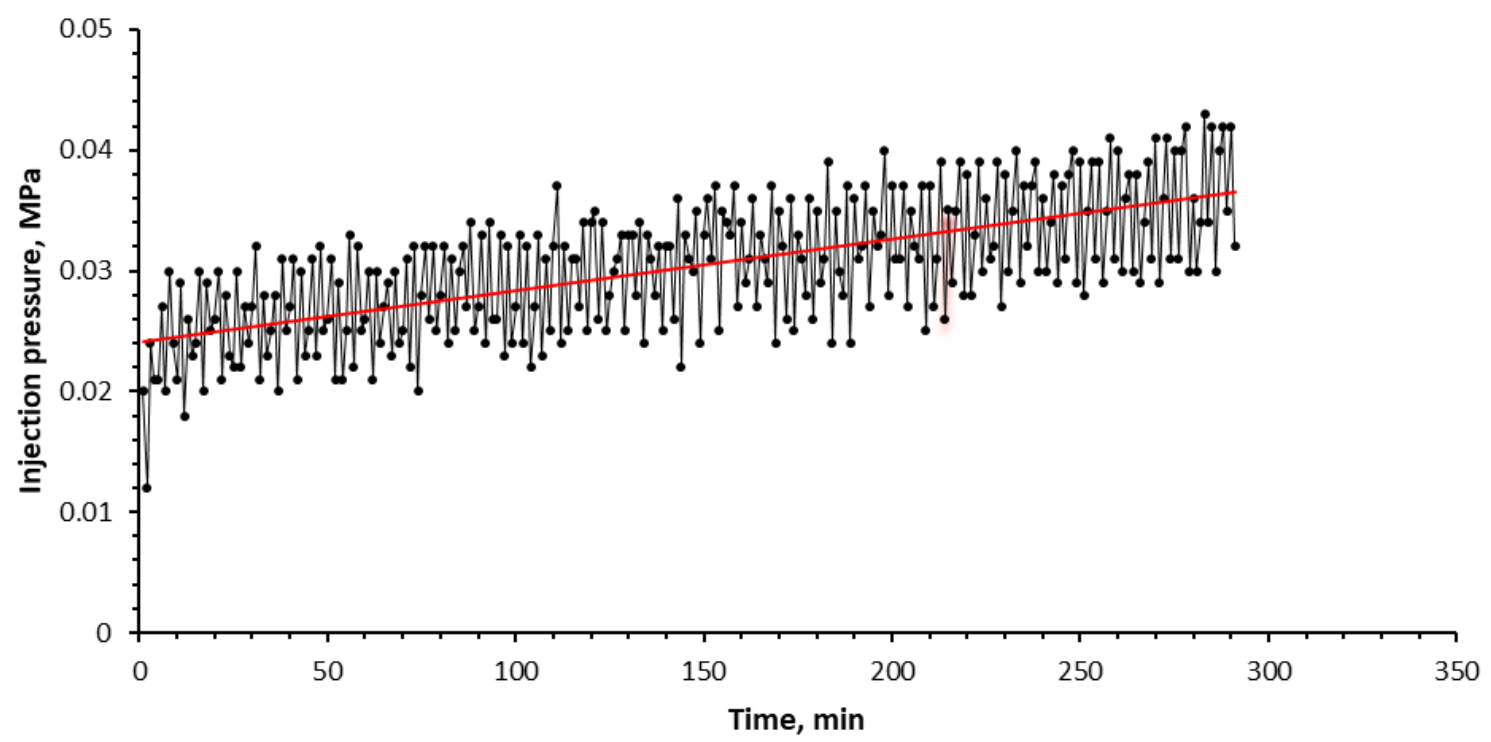

Figure 7 - Time-dependent change of pressure upon injection of saline water from "Vostochnyi Moldabek" with salinity $100 \mathrm{~g} \cdot \mathrm{L}^{-1}$ into the core sample after the injection of AMPS-APTAC-ANB (see Figure 6) and vials of collected effluents at T=25 ${ }^{\circ} \mathrm{C}$. The injection rate is $0.1 \mathrm{~mL} \cdot \mathrm{min}^{-1}$
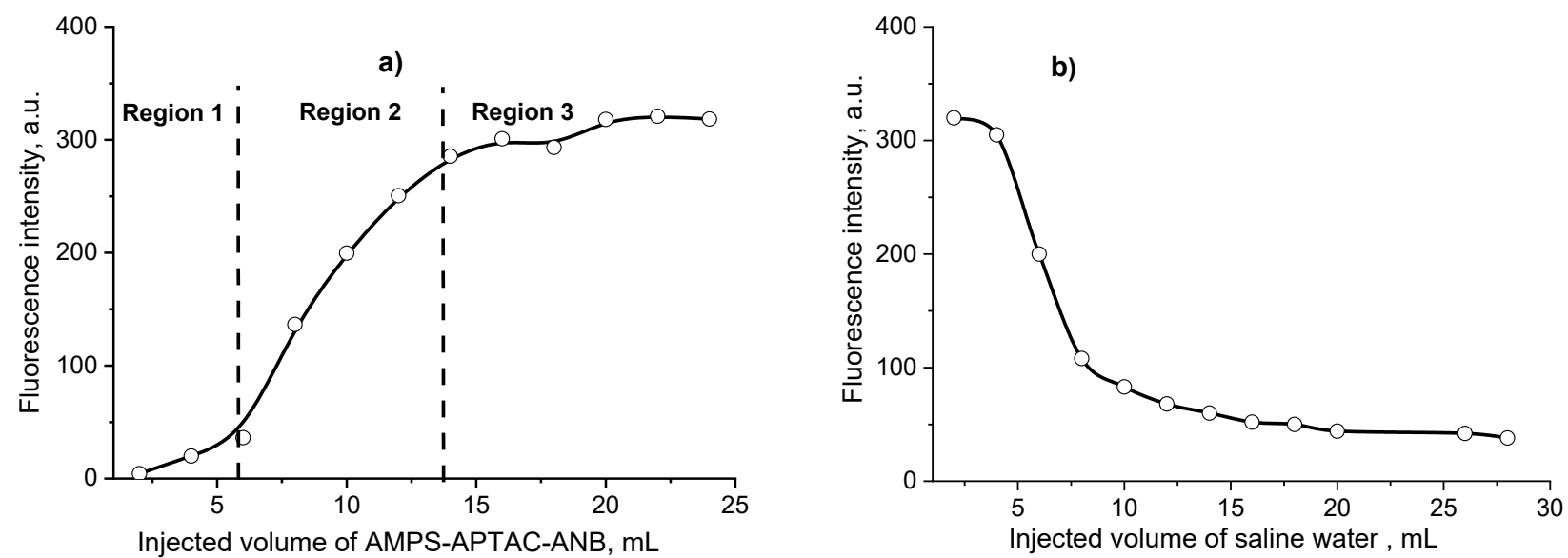

Figure 8 - Dependence of the fluorescent intensity of $0.1 \mathrm{wt}$.\% aqueous solution of AMPS-APTAC-ANB on injected volume of polymer (a) and saline water (b)

AMPS-APTAC-ANB solution injected into the core (389 a.u.). This implies that AMPS-APTAC-ANB is replaced from the core sample by saline water. Thus, the novel QPA based on AMPSAPTAC-ANB may be promising tool for evaluation of interwell and interlayer connections, as well as heterogeneities of oil reservoirs.

\section{Conclusion}

A novel ternary polyampholyte consisting of $50 \mathrm{~mol} . \%$ of anionic monomer - AMPS, 49 mol.\% of cationic monomer APTAC and 1 mol.\% of cationic fluorescent dye - ANB was synthesized and characterized as oilfield tracer. Globular, electroneutral and nano-sized macromolecules of AMPSAPTAC-ANB in aqueous and aqueous-salt solution are proved to be able to pass through porous media. It is expected that the novel AMPS-APTAC-ANB formulation might be useful as a polymer tracer for monitoring of oil wells.

\section{Acknowledgements}

This research was funded by the Science Committee of the Ministry of Education and Science of the Republic of Kazakhstan (Grant No. AP08855552). 


\section{References}

1 Kudaibergenov S.E. Polyampholytes: Synthesis, Characterization and Application. - Springer, New York, 2002.

2 Lowe A.B., McCormick C.L. Synthesis and solution properties of zwitterionic polymers // Chemical Reviews. - 2002. - Vol.102, Is.11. - P.4177-4190.

3 Kudaibergenov S., Okay O. Behaviors of quenched polyampholytes in solution and gel state // Polymers for Advanced Technologies. - 2020. - Special Issue: Review. - P.1-16.

4 Toleutay G., Shakhvorostov A., Kabdrakhmanova S., Kudaibergenov S. Solution behavior of quenched or strongly charged polyampholytes in aqueous-salt solutions // Bulletin of the Karaganda University. Chemistry Series. - 2019. - Vol.94, Is.2. - P.35-44.

5 Toleutay G., Su E., Kudaibergenov S. Swelling and mechanical properties of quenched polyampholyte hydrogels based on 2-acrylamido-2-methyl-1-propanesulfonic acid sodium salt (AMPS) and (3-acrylamidopropyl) trimethylammonium chloride (APTAC) // Bulletin of the Karaganda University. Chemistry Series. - 2019. - Vol.96, Is.4. - P.35-43.

6 Toleutay G., Dauletbekova M., Shakhvorostov A., Kudaibergenov S. Quenched polyampholyte hydrogels based on (3-acrylamidopropyl)trimethyl ammonium chloride and sodium salt of 2-acrylamido-2-methyl-1-propanesulfonic acid // Macromolecular Symposia. - 2019. - Vol.385. - ID.1800160.

7 Toleutay G., Su E., Kudaibergenov S., Okay O. Highly stretchable and thermally healable polyampholyte hydrogels via hydrophobic modification // Colloid and Polymer Science. - 2020. - Vol.98. - P.273-284.

8 Mukhametgazy N., Gussenov I., Shakhvorostov A. Quenched polyampholytes for polymer flooding // AIP Conference Proceedings. - 2019. - Vol.2167. - ID.020236.

9 Mukhametgazy N., Gussenov I., Shakhvorostov A., Kudaibergenov S. Salt tolerant acrylamide-based quenched polyampholytes for polymer flooding // Bulletin of the Karaganda University, Chemistry Series. - 2020. - Vol.100, Is.4. - P.119-127.

10 Patent for utility model of the Republic of Kazakhstan No. 5723. Method for production of fluorescent polymer tracer // Kudaibergenov S., Gussenov I., Shakhvorostov A. - Filed from 14.10.2020.

11 Serres-Piole C., Preud'homme H., Moradi-Tehrani N., Allanic C., Jullia H., Lobinski R. Water tracers in oilfield applications: Guidelines // Journal of Petroleum Science and Engineering. - 2012. - Vol.98-99. - P.22-39.

12 Конев Д.А. Исследование нефтяных пластов с помощью индикаторного метода // Современные наукоемкие технологии. - 2014. - №7(часть 2) - С.23-26.

13 Kang W.L., Hu L.L., Zhang X.F., Yang R.M., Fan H.M., Geng J. Preparation and performance of fluorescent polyacrylamide microspheres as a profile control and tracer agent // Petroleum Science. - 2015. - Vol.12. - P.483-491.

14 Yan L., Yin T., Yu W., Shen L., Lv M., Ye Z. A water-soluble oil-displacing agent with tracer properties for enhancing oil recovery // RSC Advances. - 2015. - Vol.5. - P.42843-42847.

15 Yang H., Hu L., Chen C., Gao Y., Tang X., Yin X., Kang W. Synthesis and plugging behavior of fluorescent polymer microspheres as a kind of conformance control agent in reservoirs // RSC Advances. - 2018. - Vol.8. - P.10478-10488.

\section{References}

1 Kudaibergenov SE (2002) Polyampholytes: Synthesis, Characterization and Application. Springer, New York. ISBN: 978-1-46150627-0

2 Lowe AB, McCormick CL (2002) Chem Rev 102(11): 4177-4190. https://doi.org/10.1021/cr020371t

3 Kudaibergenov S, Okay O (2020) Polym Advan Technol Special Issue Review:1-16. https://doi.org/10.1002/pat.5112

4 Toleutay G, Shakhvorostov A, Kabdrakhmanova S, Kudaibergenov S (2019) Chemistry Series 2(94): 35-44. https://doi. org/10.31489/2019Ch2/35-44

5 Toleutay G, Su E, Kudaibergenov S (2019) Bulletin of the Karaganda University, Chemistry Series 4(96):35-43.

6 Toleutay G, Dauletbekova M, Shakhvorostov A, Kudaibergenov S (2019) Macromol Symp 385:1800160. https://doi.org/10.1002/ masy. 201800160

7 Toleutay G, Su E, Kudaibergenov S, Okay O (2020) Colloid Polym Sci 298: 273-284. https://doi.org/10.1007/s00396-020-04605-8 8 Mukhametgazy N, Gussenov I, Shakhvorostov A (2019) AIP Conference Proceedings 2167:020236. https://doi. org/10.1063/1.5132103

9 Mukhametgazy N, Gussenov I, Shakhvorostov A, Kudaibergenov S (2020) Bulletin of the Karaganda University, Chemistry Series 4(100):119-127. https://doi.org/10.31489/2020Ch4/119-127

10 Kudaibergenov S, Gussenov I, Shakhvorostov A (2020) Method for production of fluorescent polymer tracer. Patent for utility model of the Republic of Kazakhstan No. 5723. Filed from 14.10.2020.

11 Serres-Piole C, Preud'homme H, Moradi-Tehrani N, Allanic C, Jullia H, Lobinski R (2012) J Petrol Sci Eng 98-99:22-39. https:// doi.org/10.1016/j.petrol.2012.08.009

12 Konev DA (2014) Modern high technologies [Sovremennye nauloemkie tehnologii] 7(2):23-26. (In Russian) 
13 Kang WL, Hu LL, Zhang XF, Yang RM, Fan HM, Geng J (2015) Pet Sci 12:483-491. https://doi.org/10.1007/s12182-015-0042-9

14 Yan L, Yin T, Yu W, Shen L, Lv M, Ye Z (2015) RSC Adv 5:42843-42847. https://doi.org/10.1039/c5ra05948h

15 Yang H, Hu L, Chen C, Gao Y, Tang X, Yin X, Kang W (2018) RSC Adv 8:10478-10488. https://doi.org/10.1039/c8ra00903a 